\title{
Sequences of the 16S rRNA genes and phylogeny of the goat mycoplasmas Mycoplasma adleri, Mycoplasma auris, Mycoplasma cottewii and Mycoplasma yeatsii
}

\author{
Malin Heldtander, ${ }^{1}$ Bertil Pettersson, ${ }^{2}$ Joseph G. Tully ${ }^{3}$ \\ and Karl-Erik Johansson ${ }^{1}$ \\ Author for correspondence: Karl-Erik Johansson. Tel: +46186740 00. Fax: +4618309162. \\ e-mail: Kaggen@sva.se
}

\footnotetext{
1 Department of Bacteriology, National Veterinary Institute, PO Box 7073, S-750 07 Uppsala, Sweden

2 Department of Biochemistry and Biotechnology, The Royal Institute of Technology, S-100 44 Stockholm, Sweden

3 Mycoplasma Section, Frederick Cancer Research and Development Center, National Institute of Allergy and Infectious Diseases, Frederick, MD 21702, USA
}

\begin{abstract}
The nucleotide sequences of the 16S rRNA genes from the type strains of four goat mycoplasmas, Mycoplasma adleri, Mycoplasma auris, Mycoplasma cottewif and Mycoplasma yeatsii, were determined by direct solid-phase DNA sequencing. Polymorphisms were found in two of the 165 rRNA gene sequences, showing the existence of two different rRNA operons. Three polymorphisms were found in $\boldsymbol{M}$. adleri, and one was found in $\boldsymbol{M}$. yeatsii. The sequence information was used for the construction of phylogenetic trees. $M$. adleri was included in the Mycoplasma lipophilum cluster within the hominis group. M. auris was comprised in the Mycoplasma hominis cluster of the hominis group. $M$. cottewii and $M$. yeatsii were found to be very closely related with only four nucleotide differences, and they grouped with Mycoplasma putrefaciens in the Mycoplasma mycoides cluster within the spiroplasma group. Sequencing of two field isolates of $M$. cottewii and $M$. yeatsii, geographically distant from the type strains, showed that the 16S rRNA gene from the field isolate of $M$. cottewif was identical to the one from the type strain. The field isolate of $M$. yeatsii had only two nucleotide differences to the type strain and these were present in only one of the two rRNA operons. Sequencing of the 165 rRNA genes from two unidentified mycoplasma isolates from Nepal indicated that they should both be regarded as $\boldsymbol{M}$. auris strains.
\end{abstract}

Keywords: goat mycoplasmas, Mycoplasma adleri, Mycoplasma auris, Mycoplasma cottewii, Mycoplasma yeatsii

\section{INTRODUCTION}

Mycoplasmas (class Mollicutes) are wall-less, freeliving bacteria that have a low $\mathrm{G}+\mathrm{C}$ content in the genome and they are closely related to Gram-positive bacteria (23). They are often host-specific, and domesticated animals usually harbour several mycoplasma species. Thus far, about 150 different mycoplasma species have been described, many of which are pathogenic, making the mycoplasmas and their phylogeny important in veterinary medicine $(25,27)$.

Classification of micro-organisms is partly based on

The GenBank accession numbers for the sequences reported in this paper are U67943-U67946.
16S rRNA data because they are supposed to reflect phylogeny (19). By this method, the mycoplasmas have been arranged in five phylogenetic groups: the hominis, pneumoniae, spiroplasma, anaeroplasma and asteroleplasma groups; and several sub-groups (22, 29). Mycoplasmas have one, two or three rRNA operons and many mycoplasmas of ruminants have two rRNA operons ( $r r n A$ and $r r n B)$. Existence of two rRNA operons has been established by restriction enzyme analysis and hybridization with rDNA probes (5) and by sequence analysis of the two operons (20, $21,24)$. A nucleotide substitution (polymorphism) in one of the operons will result in a double peak with a $1: 1$ ratio in the computerized on-line determination of the sequence from the automated sequencer. Thus, polymorphisms are easily identified and existence of 
polymorphisms in a $1: 1$ ratio shows that two rRNA operons $(20,21)$ are present.

We have determined the nucleotide sequences of the 16S rRNA genes, and established the molecular phylogeny of four recently described goat mycoplasmas. Three of these mycoplasmas, Mycoplasma auris, Mycoplasma cottewii and Mycoplasma yeatsii, were originally isolated from the external ear canal of goats in Australia (6). The fourth one, Mycoplasma adleri, was isolated from a goat's abscessed ankle in Maryland, USA (7). We have also determined the nucleotide sequences of the $16 \mathrm{~S}$ rRNA genes of four other mycoplasma isolates from goats. Two of them were isolated and typed as $M$. cottewii and $M$. yeatsii by $F$. Thiaucourt in France, and two were mycoplasmas isolated in Nepal and sent to Europe (K. Sachse \& R. Nicholas) for identification.

\section{METHODS}

Sample preparation. Strain designations, including indicated type strains, of the mycoplasmas examined in the study are given in Table 1 or in previously published reports $(6,7)$. The two strains of $M$. yeatsii were grown in $\mathrm{M}$ medium, and all the other strains were grown in HA medium (2). One millilitre of the culture suspension was centrifuged for $15 \mathrm{~min}$ at $10000 \mathrm{~g}$, washed in $1 \mathrm{ml}$ PBS $[0.14 \mathrm{M} \mathrm{NaCl}, 8.1 \mathrm{mM}$ sodium phosphate buffer ( $\mathrm{pH} 7 \cdot 4)$ ], centrifuged for another $15 \mathrm{~min}$, suspended in $1 \mathrm{ml}$ distilled water and heated in a boiling water bath for $10 \mathrm{~min}$. The suspensions were rapidly chilled on ice and stored at $-20^{\circ} \mathrm{C}$ until used.

In vitro amplification of the 165 rRNA genes. The $16 \mathrm{~S}$ rRNA genes were amplified by semi-nested PCR with four primers complementary to the universal regions $\mathrm{U} 1, \mathrm{U} 2$, U5 and $\mathrm{U} 8$, as defined by Gray et al. (10). Primers complementary to the universal regions $U 1$ and $U 8(21,22)$ were first used for the amplification of the 16S rRNA genes of the four species. The PCR products were then diluted and amplified with one primer pair complementary to regions $\mathrm{U} 1$ and U5, and another primer pair complementary to regions $\mathrm{U} 2$ and U8 $(21,22)$. These reactions generated two fragments of 900 and
$1250 \mathrm{bp}$, respectively, with an overlap of about $600 \mathrm{bp}$. The reactions were performed in $50 \mu \mathrm{l}$ volumes with $10 \mathrm{pmol}$ of each primer, $25 \mathrm{mM}$ Tris $/ \mathrm{HCl}$ buffer ( $\mathrm{pH} \mathrm{8.0)}, 50 \mathrm{mM} \mathrm{KCl}$, $2 \mathrm{mM} \mathrm{MgCl} 2,0.1 \%$ Tween $20,0.2 \mathrm{mM}$ dNTP, $0.75 \mathrm{U}$ AmpliTaq (Perkin-Elmer Cetus), and $1 \mu l$ lysed mycoplasmal suspension or diluted PCR product. Two of the primers (U5 and U8) were biotinylated to make the PCR products suitable for solid-phase DNA sequencing.

Solid-phase DNA sequencing. Forty microlitres of biotinylated PCR product was immobilized onto $200 \mu \mathrm{g}$ streptavidin-coated paramagnetic beads (Dynabeads M280; DYNAL) diluted in $40 \mu 12 \times$ binding/washing (B/W) buffer $[2 \times \mathrm{B} / \mathrm{W}$ buffer is $10 \mathrm{mM}$ Tris $/ \mathrm{HCl}$ buffer $(\mathrm{pH} 7.5)$, $1 \mathrm{mM}$ EDTA, $2.0 \mathrm{M} \mathrm{NaCl}$ ] by incubation for $15 \mathrm{~min}$ at room temperature. The tube was placed in a magnetic tube rack, to sediment the beads while the supernatant was removed. The beads were then washed in $1 \times \mathrm{B} / \mathrm{W}$ buffer and incubated in $8 \mu \mathrm{l} 0.1 \mathrm{M} \mathrm{NaOH}$ for $10 \mathrm{~min}$ at room temperature to separate the strands of the PCR product. The tube was put in the magnetic tube rack, and the alkaline supernatant, containing the eluted single strand, was removed and transferred to a new tube and neutralized with $4 \mu \mathrm{l} 0.2 \mathrm{M} \mathrm{HCl}$ and $1 \mu \mathrm{l} 1 \mathrm{M}$ Tris/HCl buffer $(\mathrm{pH} 7 \cdot 4)$. The beads were washed first with $50 \mu \mathrm{l} 0.1 \mathrm{M} \mathrm{NaOH}$, then with $40 \mu \mathrm{l} \mathrm{B} / \mathrm{W}$ buffer and finally with $50 \mu \mathrm{l}$ TE buffer $[10 \mathrm{mM}$ Tris/HCl buffer ( $\mathrm{pH} 7 \cdot 5$ ), $1 \mathrm{mM}$ EDTA]. The washed beads were diluted in $13 \mu$ distilled water $(11,12)$. The sequences were determined by the dideoxynucleotide chain-termination method with T7 DNA polymerase (Pharmacia Biotech) and fluorescently labelled primers (20-22). The samples were then loaded onto a sequencing gel of the ALFexpress automated laser fluorescent DNA sequencer (Amersham Pharmacia Biotech) followed by electrophoretic separation, on-line detection, and computerized sequence evaluation (20).

Phylogenetic analysis. Three different alignments, including the 16S rRNA sequences from the four type strains of the goat mycoplasmas determined in this work, were performed. First, to determine which phylogenetic group they belong to, all four type strain sequences were aligned with a selection of 16S rRNA sequences from Acholeplasma, Anaeroplasma, Asteroleplasma, Mycoplasma, Spiroplasma and Ureaplasma species retrieved from the database of the Ribosomal Database Project (15). Then, in two separate alignments, the sequences were compared with the respective members of the

Table 1. Mycoplasma strains from which the 165 rRNA gene sequences were determined in this work

\begin{tabular}{|llll|}
\hline Species & \multicolumn{1}{c}{ Strain } & Position of polymorphic sites* & GenBank no. $\dagger$ \\
\hline M. adleri & $\mathrm{G}^{\prime} 145^{\mathrm{T}}$ & $120_{\mathrm{C} / \mathrm{T}}, 420_{\mathrm{C} / \mathrm{T}}, 819_{\mathrm{A} / \mathrm{C}}$ & $\mathrm{U} 67943$ \\
M. auris & $\mathrm{UIA}^{\mathrm{T}}$ & Not found & $\mathrm{U} 67944$ \\
M. cottewii & $\mathrm{VIS}^{\mathrm{T}}$ & Not found & $\mathrm{U} 67945$ \\
M. cottewii & $95013-218 \mathrm{CP}$ & Not found & \\
Mycoplasma sp. & Nepal 1 & $125_{\mathrm{C} / \mathrm{T}}, 1218_{\mathrm{G} / \mathrm{T}}, 1255_{\mathrm{A} / \mathrm{G}}$ & \\
Mycoplasma sp. & Nepal 2 & $125_{\mathrm{C} / \mathrm{T}}, 1218_{\mathrm{G} / \mathrm{T}}, 1255_{\mathrm{A} / \mathrm{G}}$ & $\mathrm{U} 67946$ \\
M. yeatsii & $\mathrm{GIH}^{\mathrm{T}}$ & $218_{\mathrm{G} / \mathrm{T}}$ & \\
M. yeatsii & $95013-106 \mathrm{CG}$ & $808_{\mathrm{C} / \mathrm{T}}$ & \\
\hline
\end{tabular}

* According to the numbering of the sequences in GenBank.

$\dagger$ Only the sequences of the type strains have been deposited in GenBank. The sequences of the other strains can be deduced from the information in this table. 
groups in which they were comprised. One of these alignments was composed of representatives from the hominis group and the other consisted of members of the spiroplasma group. Gaps and ambiguities were removed from the final data sets. The two latter data sets were corrected for multiple base changes at single locations by the method of Jukes \& Cantor (14). Phylogenetic trees were constructed from all three alignments by using the neighbour-joining program (NEIGHBOR) of Saitou \& Nei (26) included in the Phylogenetic Inference Package, PHYLIP, version 3.51c (8). Bootstrap analysis was performed in sets of 500 resamplings with the SEQBOOT program.

Nucleotide sequence accession numbers. The sequences of the 16S rRNA genes from the four type strains of the goat mycoplasmas have the GenBank accession numbers listed in Table 1. Previously published 16S rRNA gene sequences were also used in this study; Acholeplasma laidlawii strain JA1, accession number M23932 (29), Anaeroplasma bactoclasticum JR ${ }^{\mathrm{T}}$, M25049 (29), Entomoplasma ellychniae ELCN-1 ${ }^{\mathrm{T}}$, M24292 (29), Mesoplasma entomophilum TAC ${ }^{\mathrm{T}}$, M23931 (29), Mycoplasma alkalescens D12 ${ }^{\mathrm{T}}$, U44764 (22), Mycoplasma arginini G230 ${ }^{\mathrm{T}}$, M24579 (29), Mycoplasma arthritidis PG6 ${ }^{\mathrm{T}}$, M24580 (29), Mycoplasma bovigenitalium PG11 ${ }^{\mathrm{T}}, \mathrm{M} 24291$ (29), Mycoplasma bovirhinis PG43 ${ }^{\mathrm{T}}$, U44766 (22), Mycoplasma bovis Donetta ${ }^{\mathrm{T}}$, U02968, U44767 $(17,22)$, Mycoplasma canadense $275 \mathrm{C}^{\mathrm{T}}$, U44769 (22), Mycoplasma capricolum subsp. capripneumoniae F38 ${ }^{\mathrm{T}}$, U26042 (21), Mycoplasma felifaucium $\mathrm{PU}^{\mathrm{T}}$, U15795 (4), Mycoplasma gateae $\mathrm{CS}^{\mathrm{T}}$, U15796 (4), Mycoplasma hominis PG21 ${ }^{\mathrm{T}}$, M24473 (29), Mycop'asma lipophilum MaBy ${ }^{\mathrm{T}}$, M24581 (29), Mycoplasma mycoides subsp. capri PG3 ${ }^{\mathrm{T}}$, U26036 (21), Mycoplasma mycoides subsp. mycoides SC, PGI ${ }^{\mathrm{T}}, \mathrm{U} 26038$ (21), Mycoplasma penetrans GTU54 ${ }^{\mathrm{T}}$, L10839 (1), Mycoplasma pneumoniae $\mathrm{FH}^{\mathrm{T}}$, M29061 (29), Mycoplasma putrefaciens $\mathrm{KS}-1^{\mathrm{T}}$, U26055 (22), Mycoplasma synoviae WVU853 $^{\mathrm{T}}$, L07757 (18), Spiroplasma apis B-31 $1^{\mathrm{T}}$, M23937 (29), and Spiroplasma citri Maroc ${ }^{\mathrm{T}}, \mathrm{M} 23942$ (29).

\section{RESULTS AND DISCUSSION}

Sequences of the 165 rRNA genes of the $M$. adleri, $M$. auris, $M$. cottewii and $M$. yeatsii type strains

Almost full-length sequences (96\%) of the 16S rRNA genes of the goat mycoplasmas were obtained by solidphase DNA sequencing. Sequence data of the termini of the 16S rRNA genes are lacking, since PCR primers complementary to the termini of the genes were used for amplification. Polymorphic positions (Table 1) were observed in $M$. adleri and $M$. yeatsii; there were three and one of these in the respective species. The nucleotides were present in a $1: 1$ ratio in the polymorphic positions, which proves the existence of two different rRNA operons in these species $(20,21)$. In $M$. auris and $M$. cottewii no such microheterogeneities were identified. This finding does not, however, show that these two species only have one rRNA operon each, they are as likely to contain two rRNA operons with identical 16S rRNA sequences. This is particularly probable in the case of $M$. cottewii, judging from its close relatedness to $M$. yeatsii which has one polymorphism (see below), and to $M$. putrefaciens which has been shown to harbour two 16S rRNA genes (21).

\section{Phylogenetic analysis of the type strains}

The first alignment, including the sequences of the four type strains and representatives from all five major groups of the mycoplasma phylogenetic tree (29), resulted in a tree where $M$. adleri and $M$. auris were placed in the hominis group, whereas $M$. cottewii and $M$. yeatsii were shown to belong to the spiroplasma group (data not shown). Two separate final alignments were performed because these two groups are relatively distant in the mycoplasma phylogeny. One alignment included representatives from the different clusters in the hominis group and the other included the $M$. mycoides cluster and some representatives for the other clusters of the spiroplasma group. The final alignments comprised 1309 and 1334 nucleotides of the 16S rRNA sequences, respectively. Anaeroplasma bactoclasticum and $M$. pneumoniae served as outgroups in the phylogenetic trees which are shown in Figs 1 and 2, respectively. The phylogenetic tree of the members of the hominis group showed that $M$. adleri is most closely related to $M$. felifaucium with a $97.0 \%$ similarity. $M$. adleri is also $96.0 \%$ similar to both $M y c o-$ plasma agalactiae and $M$. bovis. This shows that $M$. adleri should be included in the $M$. lipophilum cluster of the hominis group (Fig. 1). The same phylogenetic analysis also showed that $M$. auris is most closely related to $M$. alkalescens in the hominis cluster of the hominis group (Fig. 1). M. auris showed a $98.9 \%$ similarity to $M$. alkalescens, $98.6 \%$ similarity to $M$. canadense, $98.3 \%$ similarity to $M$. arginini, and a $98.2 \%$ similarity to $M$. gateae .

$M$. cottewii and $M$. yeatsii are very closely related $(99.7 \%$ similarity) with only four nucleotide differences. The final analysis including members of the spiroplasma group revealed that phylogenetically they belong to the $M$. mycoides cluster in the spiroplasma group (Fig. 2). They branch with $M$. putrefaciens to which they both show $98.9 \%$ similarity.

\section{The M. mycoides cluster of the spiroplasma group}

Four distinct phylogenetic clusters of the spiroplasma group were defined by Woese and co-workers (29). They were denoted as the $M$. mycoides cluster, the Spiroplasma apis cluster, the Spiroplasma citri cluster and the Spiroplasma sp. strain Y-32 cluster, with a nomenclature associated to a representative member of each of the clusters. The classical $M$. mycoides cluster is composed of Mycoplasma capricolum subsp. capricolum, $M$. capricolum subsp. capripneumoniae, $M$. mycoides subsp. capri, M. mycoides subsp. mycoides LC type, M. mycoides subsp. mycoides SC type, and Mycoplasma sp., bovine group 7. However, in the phylogenetic $M$. mycoides cluster $M$. putrefaciens, $E$. ellychniae and Mesoplasma entomophilum were also included (29). When more 16S rRNA sequence information from mycoplasmas of the spiroplasma group becomes available, it may be possible to define more clusters in this group, and confusion with the classical $M$. mycoides cluster can then be avoided. For 


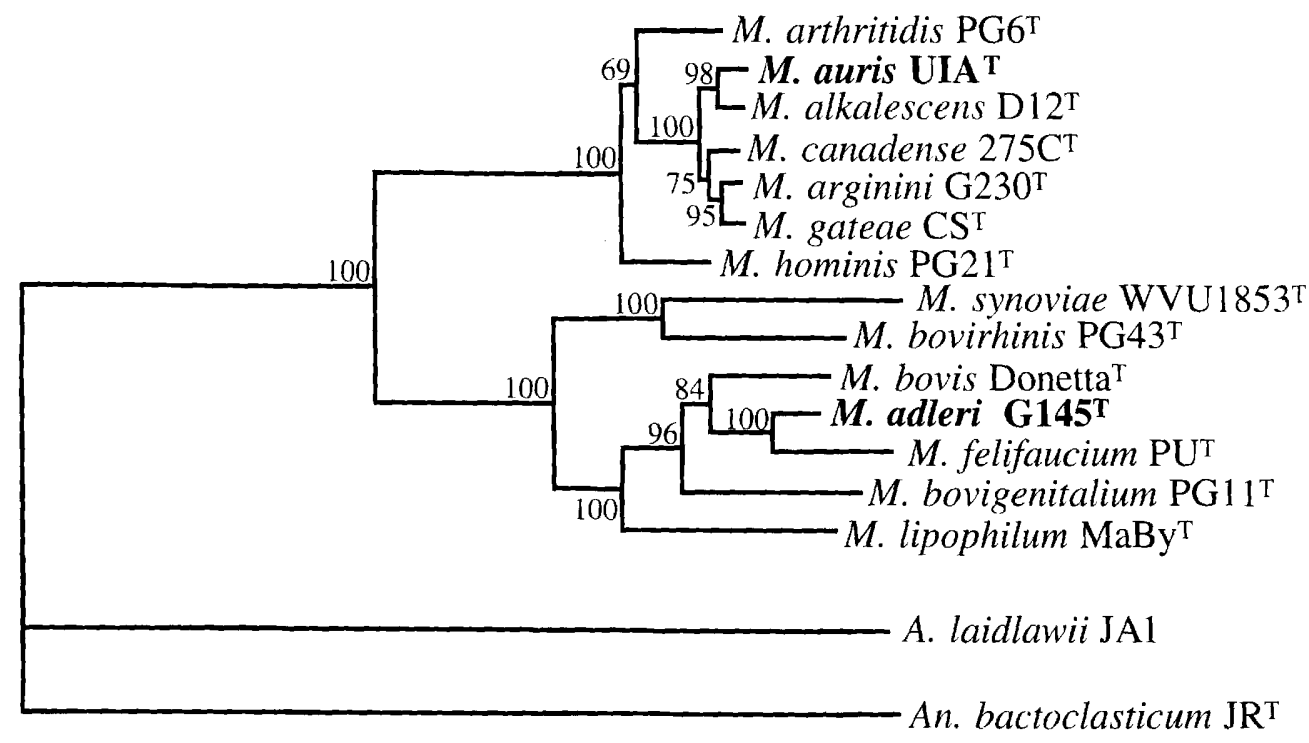

10

Fig. 1. Phylogenetic tree based on distance matrix analysis of 1309 positions in the 165 rRNA gene sequences from $M$. adleri and $M$. auris sequenced in this work and 14 representatives of the hominis group (29). The 16S rRNA sequence from Anaeroplasma bactoclasticum served as the outgroup. Bootstrap percentage values obtained from 500 resamplings of the data set are given at the nodes. The scale bar indicates substitutions per 100 nucleotide positions.

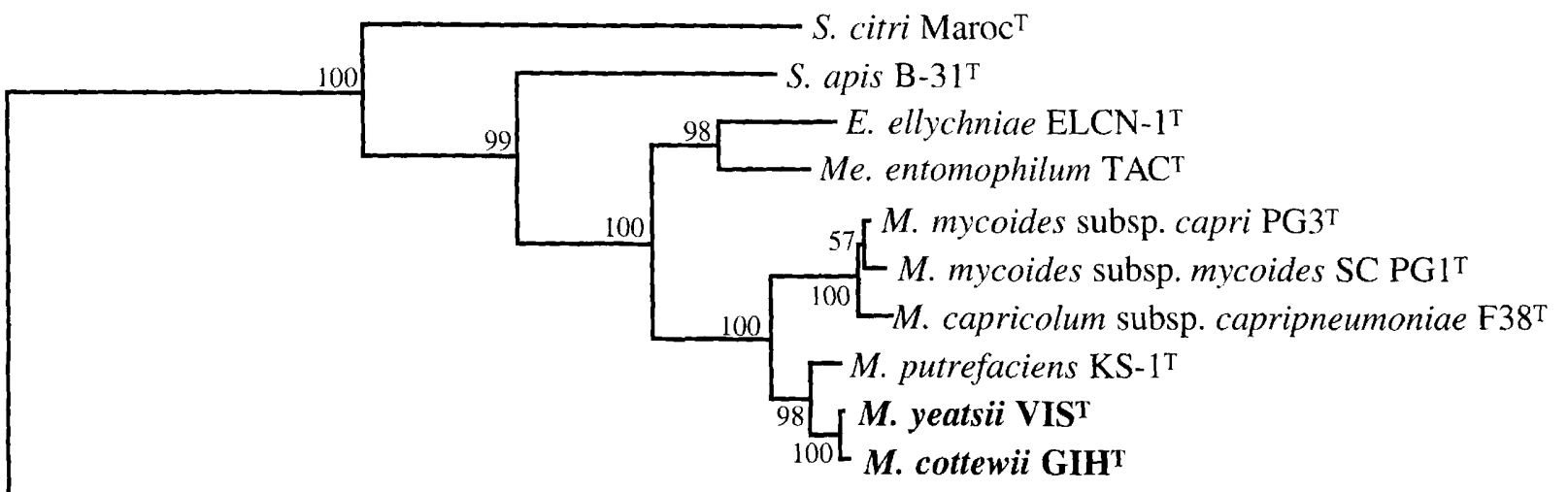

M. penetrans GTU54T

M. pneumoniae $\mathrm{FH}^{\mathrm{T}}$

Fig. 2. Phylogenetic tree based on distance matrix analysis of 1334 positions in the 165 rRNA gene sequences from $M$. cottewii and $M$. yeatsii sequenced in this work and eight representatives of the spiroplasma group (29). The 16S rRNA sequence from $M$. pneumoniae served as the outgroup. Bootstrap percentage values obtained from 500 resamplings of the data set are given at the nodes. The scale bar indicates substitutions per 100 nucleotide positions.

instance, our data indicate that $M$. putrefaciens, $M$. cottewii and $M$. yeatsii should be included in a separate cluster. These three species have 26 characteristic nucleotide positions in common, which they do not share with the members of the classical $M$. mycoides cluster. 


\section{Analysis of the field isolates}

The 16S rRNA gene sequence of the field isolate of $M$. cottewii was identical to that of the type strain of the species, and the sequence from the $M$. yeatsii field isolate had only two nucleotide differences from that of the type strain. Both of these differences were found in polymorphic positions and each of them is therefore only present in one of the operons (Table 1).

The sequences of the two field strains from Nepal were identical except for one single nucleotide difference. They were closely related to $M$. auris $\left(\mathrm{UIA}^{\mathrm{T}}\right)$ to which they showed $99.8 \%$ identity. The $0.2 \%$ difference was due to three polymorphic positions that were present in the strains from Nepal but not in $M$. auris (UIA ${ }^{\mathrm{T}}$ ). This observation indicates that the two isolates are of the same species and that they should be regarded as strains or variants of $M$. auris, which has to be verified by serological studies or by DNA-DNA reassociation experiments.

\section{Species designation, classification and diagnostics based on 165 rRNA sequence data}

Designating a new mycoplasma species requires, beside the definition of some cultural and biochemical characteristics, a detailed serological analysis including the testing against antisera to all previously described species in the genus (13). Today the number of species described within the genus Mycoplasma is about 100, and increases by about 10 per year. This testing has therefore not only become a rather extensive work, but it is also very difficult for one laboratory to keep all these antisera in stock. It is, therefore, imperative in the long run to use another strategy to designate new species of the class Mollicutes. The 16S rRNA gene has already been proposed as a possible tool for the classification of the mycoplasmas $(13,16,29)$, and it would also be a useful tool for designating a new mycoplasma species, if sequence information from the 16S rRNA genes of all known Mycoplasma species were available. We therefore suggest that the $16 \mathrm{~S}$ rRNA genes of all described species of the class Mollicutes should be sequenced. After having found a potentially new species it would then be sufficient to analyse the isolate with antisera against the members of its phylogenetic cluster. Following this procedure, only 5-15 serological tests would be required to establish that an isolate was a new species within the genus Mycoplasma.

Our sequence data for $M$. cottewii and $M$. yeatsii illustrate an important problem which has been addressed by others $(9,28)$. When two $16 \mathrm{~S}$ rRNA sequences are very similar, it is always difficult to know if the corresponding organisms should be grouped within the same or within different species. This problem has also been observed for other mycoplasmas. For instance, Mycoplasma gallisepticum and Mycoplasma imitans have been shown to have only two nucleotide differences in their $16 \mathrm{~S}$ rRNA sequences, but other characteristics show that they should be regarded as different species (3). Furthermore, $M$. mycoides subsp. capri and $M$. mycoides subsp. mycoides LC type have only three nucleotide differences in their 16S rRNA genes (21), but are still regarded as two different subspecies. Phylogenetic trees based on sequences with too few nucleotide differences are not always reliable, for instance when more than two species are included. Therefore, the stabilities of the nodes may be low, and consequently the branching order may be difficult or even impossible to establish with certainty. This problem has been shown for the $M$. capricolum species group of the $M$. mycoides cluster (24). However, the $M$. mycoides cluster and the $M$. putrefaciens cluster in Fig. 2 probably represent two monophyletic groups and in phylogenetic trees based on 16S rRNA sequences, $M$. cottewii and $M$. yeatsii will always form a tight cluster. It is impossible to give a general rule about how many nucleotide differences there should be in the $16 \mathrm{~S}$ rRNA genes of two organisms to be classified as different species, because rRNA genes evolve at different rates in different groups of organisms. However, if the $16 \mathrm{~S}$ rRNA sequence identity for two species is below $97 \%$, they are likely to represent different species (28). It may be possible to give more precise figures for certain taxa, for instance for the class Mollicutes or for the genus Mycoplasma. For classification of closely related species with 16S rRNA sequence identities between 97 and $100 \%$, it is essential to consider data other than those obtained by 16S rRNA analysis, for instance DNA-DNA reassociation data or serological data. It has been suggested that a DNA-DNA reassociation value below $70 \%$ must be obtained to support delineation of two organisms into different species, when the $16 \mathrm{~S}$ rRNA identity is $97-100 \%$ (28). Sequence analysis of essential genes other than the 16S rRNA genes may also be useful for classification of organisms, even if the 16S rRNA gene is the first choice, for several reasons (19). When more sequence data become available from whole bacterial genome projects, it will be easier to select other suitable genes for phylogenetic studies of closely related species, where the resolution of the $16 \mathrm{~S}$ rRNA method is too low.

\section{ACKNOWLEDGEMENTS}

We thank François Thiaucourt (CIRAD-EMVT, Montpellier, France) for supplying the field strains of $M$. cottewii and $M$. yeatsii, and Robin Nicholas (VLA, Addlestone, UK) and Konrad Sachse (BgVV, Jena, Germany) for supplying the two Nepalese field strains. We are grateful to Göran Bölske for many discussions and to Virginia Melys for valuable technical assistance. This work was financially supported by grants from the Research Foundation of SVA (National Veterinary Institute). The project forms a part of the EU research collaboration project COST 826 on 'Ruminants' Mycoplasmoses'.

\section{REFERENCES}

1. Behbahani, N., Blanchard, A., Cassell, G. H. \& Montagnier, L. (1993). Phylogenetic analysis of Mycoplasma penetrans isolated from HIV-infected patients. FEMS Microbiol Lett 109, 63-66. 
2. Bölske, G. (1988). Survey of mycoplasma infections in cell cultures and a comparison of detection methods. Zentralbl Bakteriol Hyg A 269, 331-340.

3. Bradbury, J. M., Abdul-Wahab, O. M. S., Yavari, C. A., Dupiellet, J.-P. \& Bové, J. M. (1993). Mycoplasma imitans sp. nov. is related to Mycoplasma gallisepticum and found in birds. Int J Syst Bacteriol 43, 721-728.

4. Brown, D. R., McLaughlin, G. S. \& Brown, M. B. (1995). Taxonomy of the feline mycoplasmas Mycoplasma felifaucium, Mycoplasma feliminutum, Mycoplasma felis, Mycoplasma gateae, Mycoplasma leocaptivus, Mycoplasma leopharyngis, and Mycoplasma simbae by $16 \mathrm{~S}$ rRNA gene sequence comparisons. Int J Syst Bacteriol 45, 560-564.

5. Christiansen, G. \& Ernø, H. (1990). RFLP in rRNA genes of Mycoplasma capricolum, the caprine F38-like group and the bovine serogroup 7. Zentralbl Bakteriol Hyg Suppl 20, 479-488.

6. DaMassa, A. J., Tully, J. G., Rose, D. L., Pitcher, D., Leach, R. H. \& Cottew, G. S. (1994). Mycoplasma auris sp. nov., Mycoplasma cottewii sp. nov., and Mycoplasma yeatsii sp. nov., new sterol-requiring mollicutes from the external ear canals of goats. Int J Syst Bacteriol 44, 479-484.

7. Del Giudice, R. A., Rose, D. L. \& Tully, J. G. (1995). Mycoplasma adleri sp. nov., an isolate from a goat. Int $J$ Syst Bacteriol 45, 29-31.

8. Felsenstein, J. (1993). PHYLIP: Phylogeny Inference Package (version 3.51c). Department of Genetics, University of Washington, Seattle, USA.

9. Fox, G. E., Wisotzkey, J. D. \& Jurtshuk, P. (1992). How close is close: $16 \mathrm{~S}$ rRNA sequence identity may not be sufficient to guarantee species identity. Int $J$ Syst Bacteriol 42, 166-170.

10. Gray, M. W., Sankoff, D. \& Cedergren, R. J. (1984). On the evolutionary descent of organisms and organelles: a global phylogeny based on a highly conserved structural core in small subunit ribosomal RNA. Nucleic Acids Res 12, $5837-5852$

11. Hultman, T., Bergh, S., Moks, T. \& Uhlén, M. (1991). Bidirectional solid-phase sequencing of in vitro-amplified plasmid DNA. Biotechniques 10, 84-93.

12. Hultman, T., Ståhl, S., Hornes, E. \& Uhlén, M. (1989). Direct solid phase sequencing of genomic and plasmid DNA using magnetic beads as solid support. Nucleic Acids Res 17, $4937-4946$.

13. International Committee on Systematic Bacteriology Subcommittee on the Taxonomy of Mollicutes (1995). Revised minimum standards for description of new species of the class Mollicutes (division Tenericutes). Int $J$ Syst Bacteriol 45, 605-612.

14. Jukes, T. H. \& Cantor, C. R. (1969). Evolution of protein molecules. In Mammalian Protein Metabolism, pp. 21-132. Edited by H. N. Munro. New York: Academic Press.

15. Maidak, B. L., Larsen, N., McCaughey, M. J., Overbeek, R., Olsen, G. J., Fogel, K., Blandy, J. \& Woese, C. R. (1996). The ribosomal database project. Nucleic Acids Res 24, 82-85.

16. Maniloff, J. (1992). Phylogeny of mycoplasmas. In $\mathrm{Myco}$ - plasmas: Molecular Pathology and Pathogenesis, pp. 549-559. Edited by J. Maniloff, R. N. McElhaney, L. R. Finch \& J. B. Baseman. Washington, DC: American Society for Microbiology.

17. Mattsson, J. G., Guss, B. \& Johansson, K.-E. (1994). The phylogeny of Mycoplasma bovis as determined by sequence analysis of the 16S rRNA gene. FEMS Microbiol Lett 325-328.

18. Morrow, C. J. (1990). Pathogenicity, immunogenicity and strain identification of Australia isolates of Mycoplasma synoviae. PhD thesis, University of Melbourne.

19. Olsen, G. J. \& Woese, C. R. (1993). Ribosomal RNA : a key to phylogeny. FASEB J 7, 113-123.

20. Pettersson, B., Johansson, K.-E. \& Uhlén, M. (1994). Sequence analysis of $16 \mathrm{~S}$ rRNA from mycoplasmas by direct solidphase DNA sequencing. Appl Environ Microbiol 60, 2456-2461.

21. Pettersson, B., Leitner, T., Ronaghi, M., Bölske, G., Uhlén, M. \& Johansson, K.-E. (1996). Phylogeny of the Mycoplasma mycoides cluster as determined by sequence analysis of the $16 \mathrm{~S}$ rRNA genes from the two rRNA operons. $J$ Bacteriol 178, 4131-4142.

22. Pettersson, B., Uhlén, M. \& Johansson, K.-E. (1996). Phylogeny of some mycoplasmas from ruminants based on $16 \mathrm{~S}$ rRNA sequences and definition of a new cluster within the hominis group. Int J Syst Bacteriol 46, 1093-1098.

23. Razin, S. (1992). Mycoplasma taxonomy and ecology. In Mycoplasmas: Molecular Pathology and Pathogenesis, pp. 3-22. Edited by J. Maniloff, R. N. McElhaney, L. R. Finch \& J. B. Baseman. Washington, DC: American Society for Microbiology.

24. Ros Bascuñana, C., Mattsson, J. G., Bölske, G. \& Johansson, K.-E. (1994). Characterization of the $16 \mathrm{~S}$ rRNA genes from Mycoplasma sp. strain F38 and development of an identification system based on PCR. J Bacteriol 176, 2577-2586.

25. Ross, R. F. (1993). Mycoplasma-animal pathogens. In Rapid Diagnosis of Mycoplasmas, pp. 69-95. Edited by I. Kahane \& A. Adoni. New York: Plenum.

26. Saitou, N. \& Nei, M. (1987). The neighbor-joining method: a new method for reconstructing phylogenetic trees. Mol Biol Evol 4, 406-425.

27. Simecka, J. W., Davis, J. K., Davidson, M. K., Ross, S. E., Städtlander, C. T. K.-H. \& Cassell, G. H. (1992). Mycoplasma diseases of animals. In Mycoplasmas: Molecular Pathology and Pathogenesis, pp. 391-415. Edited by J. Maniloff, R. N. McElhaney, L. R. Finch \& J. B. Baseman. Washington, DC: American Society for Microbiology.

28. Stackebrandt, E. \& Goebel, B. M. (1994). Taxonomic note: a place for DNA-DNA reassociation and 16S rRNA sequence analysis in the present species definition in bacteriology. Int $J$ Syst Bacteriol 44, 846-849.

29. Weisburg, W. G., Tully, J. G., Rose, D. L., Petzel, J. P., Oyaizu, H., Yang, D., Mandelco, L., Sechrest, J., Lawrence, T. G., van Etten, J., Maniloff, J. \& Woese, C. R. (1989). A phylogenetic analysis of the mycoplasmas: basis for their classification. $J$ Bacteriol 171, 6455-6467. 